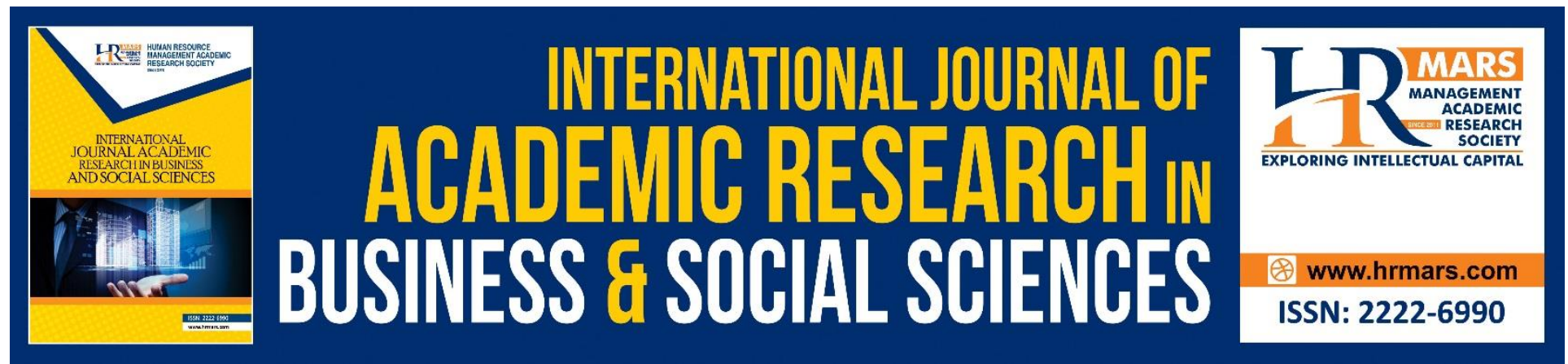

\title{
Impact of 'Green' Product Label Standards on Consumer Behaviour: A Systematic Review Analysis
}

Ihemezie, Eberechukwu Johnpaul

Ukwuaba, Ikenna Charles

Nnaji, Amaka Precious

To Link this Article: http://dx.doi.org/10.6007/IJARBSS/v8-i9/4647

DOI: $\quad 10.6007 /$ IJARBSS/v8-i9/4647

Received: 06 August 2018, Revised: 27 August 2018, Accepted: 29 Sept 2018

Published Online: 15 October 2018

In-Text Citation: (Ihemezie, Ukwuaba, \& Nnaji, 2018)

To Cite this Article: Ihemezie, E. J., Ukwuaba, I. C., \& Nnaji, A. P. (2018). Impact of 'Green' Product Label Standards on Consumer Behaviour: A Systematic Review Analysis. International Journal of Academic Research in Business and Social Sciences, 8(9), 666-684.

Copyright: (C) 2018 The Author(s)

Published by Human Resource Management Academic Research Society (www.hrmars.com)

This article is published under the Creative Commons Attribution (CC BY 4.0) license. Anyone may reproduce, distribute, translate and create derivative works of this article (for both commercial and non-commercial purposes), subject to full attribution to the original publication and authors. The full terms of this license may be seen

at: http://creativecommons.org/licences/by/4.0/legalcode

\begin{tabular}{|l|l|}
\hline \multicolumn{2}{|c|}{ Vol. 8, No. 9, September 2018, Pg. $666-684$} \\
\hline http://hrmars.com/index.php/pages/detail/IJARBSS & JOURNAL HOMEPAGE \\
\hline
\end{tabular}

Full Terms \& Conditions of access and use can be found at http://hrmars.com/index.php/pages/detail/publication-ethics 


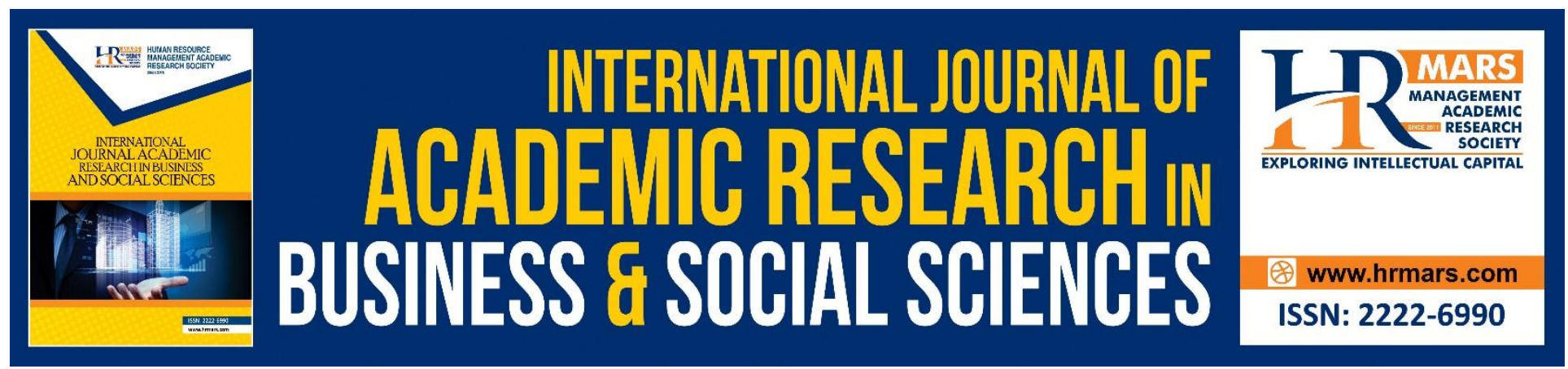

\title{
Impact of 'Green' Product Label Standards on Consumer Behaviour: A Systematic Review Analysis
}

\author{
Ihemezie, Eberechukwu Johnpaul
}

Department of Agricultural Economics, Faculty of Agriculture, University of Nigeria Nsukka, Enugu State, Nigeria. Corresponding Author: eberechukwu.ihemezie@unn.edu.ng

\section{Ukwuaba, Ikenna Charles}

Department of Agricultural Economics, Faculty of Agriculture, University of Nigeria Nsukka, Enugu State, Nigeria. Email: Ikenna.ukwuaba@unn.edu.ng

\section{Nnaji, Amaka Precious}

Department of Agricultural Economics, Faculty of Agriculture, University of Nigeria Nsukka, Enugu State, Nigeria. Email: amaka.nnaji@unn.edu.ng

\begin{abstract}
There have been controversies surrounding the actual effect of 'green' product labels in influencing consumers towards eco-friendly behaviours. While some claim that the proliferation of private business standards are confusing rather than assisting eco-friendly consumers in their green purchasing decisions, others posit that it has had significant positive effect in influencing consumers towards 'green' purchasing. Still yet, some others found neutral effect of 'green' labels on consumer behaviour. The objective of this critical review is to determine if available evidencebased studies on the use of 'green' labels support or contradict the above claims, using a systematic review approach. This review adopted an analytical framework developed by Gupta et al. (2006) for modeling the impact of business programs on customer lifetime value (CLV). The result of the analysis confirmed varied effect of eco labels among different classes of consumers and for different products in developed and developing economies. Further evidence abounds of both positive impacts (customer acquisition and sustained patronage of eco-labelled products) and negative impacts (confusing/discouraging consumers due to generic information or high price of eco-labelled products). There is also little evidence of no impact, which suggests that eco-labels alone may not be sufficient to influence consumer behaviour. Further empirical research on the impact of eco-labels on product utilization and disposal was recommended.
\end{abstract}


INTERNATIONAL JOURNAL OF ACADEMIC RESEARCH IN BUSINESS AND SOCIAL SCIENCES

Vol. 8, No. 9, Sept. 2018, E-ISSN: 2222-6990 @ 2018 HRMARS

Keywords: Eco-labels, Consumer Behaviour, Environmental Impacts, Systematic Review Approach, Consumer Life Time Value, Eco-Friendly Consumers.

\section{Introduction}

In the last couple of years, heightened interests to mitigate the harmful impacts of business activities on the environment have given rise to the need to assess the environmental impact of business products, starting from production to consumption (Santos, 2007). According to Dagher and Itani (2014), and Scott and Vigar-ellis (2014), one vital element in this chain of life cycle assessment is the understanding of Consumer Behaviour (CB)- which explains the decision making process that determines how consumers purchase, use and dispose products (Ghafelehbashi, 2011). There has been claims that consumption impacts the environment (Zepeda et al., 2013; Vanyushyn, 2011; Thøgersen et al., 2010; Horne, 2009). However, the extent of this impact depends on how consumers choose to purchase, utilize, and dispose products (Testa et al., 2015). Hence, consumers' demand for eco-friendly products will contribute to environmental wellbeing and to a large extent drive businesses to produce more eco-friendly products. Meanwhile, while the environmental concern is to reduce the harmful effect of consumption on the environment through production of eco-friendly products (Gallastegui, 2002), the business viewpoint reckons that investing in eco-friendly products will be of little benefit if consumers don't adopt them (Testa et al., 2015). One strategy that has been developed to bridge the above environmental concern and business interest is the development and use of 'green' label standards, otherwise known as eco-labels. Green labels thus serve three general purposes: 1) influence CB towards eco-friendly consumption; 2) as a marketing tool for businesses to differentiate their products and attract green consumers- i.e. consumers who are concerned about the environmental consequences of their consumption lifestyle; 3) induce businesses to improve the environmental standard of their products.

According to Gallastegui (2002), 'green' product label standards influence CB in two ways. First, they introduce and initiate the concept of 'green' as an attribute to be considered by consumers at the point of purchase. Secondly, they allow/assist consumers to shop for green products in comparison to conventional products. In other words, they make it easier for consumers to differentiate between more sustainable products and less sustainable products. A search of literature on 'green' labels reveals three distinct but related theoretical assumptions that underpin the development and usage of 'green' labels. First is the assumption that consumers will be influenced to move towards more sustainable purchasing if presented with 'green' labels or 'green' label information that differentiate products produced in a sustainable manner from conventional products (Whitson et al., 2014; Sammer and Wüstenhagen, 2006). Second is the assumption that more consumers are increasingly becoming aware of the environmental consequences of their consumption behaviour, and hence are becoming more environmental conscious in their consumption, i.e. moving towards social or ethical consumption pattern. It is thus hoped that providing a green label will facilitate their eco-friendly consumption decisions (Royne et al., 2011). The third assumption is that as a result of the emergence of more proenvironmental consumers, the willingness to pay a premium for eco-certified products, and thus support businesses that engage in sustainable production will be enhanced (Harms and Linton, 2015; Rourke and Ringer, 2015). The main objective of this review is therefore to determine if 
available evidence-based studies on the use of 'green' labels support or contradict the above theoretical assumptions.

However, certain problems have been identified with the use of labels to promote eco-friendly consumption. Such problems such as the issue of trust and authenticity of labels, and excess generic sustainability information on a label tend to confuse consumers rather than aid their ecofriendly consumption. Thus the need to critically ascertain the true impacts of green label standards on consumer behaviour becomes a vital research issue for sustainability enthusiasts and business development experts.

Previous studies have attempted to examine the impacts of eco-labels on consumer behavious. However, most are either limited to a particular industry or a particular green label. This study is an attempt to explore the collective impacts of green label standards on a wide range of industries and goods, by analyzing and synthesizing disaggregated pieces of relevant empirical works. The overall aim is to provide a comprehensive review of literature to ascertain what impact green' label standards have had on CB. This is because; recent findings are indicating that eco-labels have varied impacts on CB (Harms and Linton, 2015; Scott and Vigar-ellis, 2014; Connell, 2010). In fact there are evidences that suggest that the proliferation of private business standards in the market today is confusing eco-friendly consumers rather than assisting their green purchasing decisions (Yau, 2012; Brécard et al., 2009). In the same vein, although it has been shown that 'green' labels have positive impact on the knowledge of eco-friendly product and intention of consumers to purchase, other studies have also indicated that the presence of a 'green' label on product does not automatically translate to 'green' purchasing (Sonnenberg et al., 2014; Vanclay et al., 2011). All these disparities about the impact of 'green' product label standards on CB call for a critical review of literatures that provide evidence on the subject. Ascertaining the impacts of 'green' product label standards on CB will contribute to efforts towards curtailing the impacts of consumption on the environment, and thus promoting environmental wellbeing. A critical review of research evidence in this direction promises to provide a robust and comprehensive analysis useful for policy making.

To achieve this, an analytical framework developed by Gupta et al. (2006) to assess the impact of business strategies on customer life time value was adopted and modified. The review proceeds by first presenting an outline of the methodology employed in selecting the reviewed articles. This is followed by the synthesis of results according to the nature of impact 'green' product labels have had on CB. Next, is the presentation of the analytical framework for the analysis of the results. Then the results were discussed in the light of the modified framework. Finally, the report concludes by summarising the findings of the review, and suggesting direction for future research.

\section{Methodology}

Given that this report is an evidence-based review, a systematic review approach was adopted. This approach according to Moher et al. (2015) helps to eliminate bias and ensures a comprehensive review of all but only relevant literature on a subject. In order not to limit the scope of the evidences, all peer-reviewed articles, industry publications, university PhD thesis were considered for inclusion. First, the data source started with an unrestricted keyword search on Google for the terms 'green label(ing) and CB', 'eco-label(ing) and CB', 'environmental label(ing) and CB', 'impacts of eco-labels on CB. This first step yielded 2,390 and 212 articles 
(peer-reviewed journal articles and grey literatures inclusive). The search was further extended to other relevant databases such as; Wiley online library, Emerald Fulltext, Academic Search Premier, EBSCO, Web of Science, Science Direct, and Google Scholar, specifically for peerreviewed journal articles. After sorting out articles repeated in other databases, the result came down to a total of 1,085 articles. Furthermore, articles with only abstracts whose full text could not be retrieved were dropped, bringing the results further down to 1,035 . Then the reference lists of the selected articles were searched for further evidences. However, for any article to be included in the data set for the review, it must meet the following three criteria.

First, the article must be published between year 2010 and 2016. This is primarily to ensure that only articles relevant to the contemporary 'green label-CB' debates are used for the review. This decision was based on the findings of Manzano et al. (2012) who noted that CBs are constantly changing as consumer preference and tastes changes, fuelled by the increase in knowledge, and availability of more information. Hence, articles published from 2010 rightly reflect the most recent trend and state of $\mathrm{CB}$. Furthermore, since the life-cycle of most standards are fairly short, or are often revised after every 4-5 years to reflect up-to-date technical innovation in production and market changes (Golden, 2010), concentrating on literatures published within the last 5 years seems most suitable to capture only relevant evidences on the impacts of green label products on $\mathrm{CB}$.

Secondly, a careful study of all the articles that met the first criteria reveals that not all of them provided evidence on the impact of 'green' labels on CB. For instance, articles focusing on the awareness of 'green' labels by consumers were excluded. In other words, only articles that assessed the impact of 'green' labels on the CB were included in the data set for the review.

Thirdly, the article must assess the impact of any known 'green' product label standard. This means that articles that focused on general assessment of eco-labels without reference to any of the already existing standards for an industry or popular in a country were filtered out. This criteria was set because the aim of the report is to review evidences of the impacts of already existing 'green' label standards on CB, and not just a theoretical appraisal of what impacts green' label standards should have on CB.

This approach gave rise to a total of 18 articles on the impact of 'green' product labels on CB used for this review. Out of these 18 articles, 15 are peer-reviewed journal articles while 3 are grey literature. Out of the 15 peer-reviewed journal articles, 13 are empirical primary studies, while 2 are review article. The 3 grey literatures are industry reports. Furthermore, 4 of the articles focused on the food industry, 3 on sea products, 3 on energy and electrical appliances such as washing machines, 2 on forest products, 1 on textile and apparel industry, 1 on building, 1 on personal care products such as laundry detergents, while the rest are on general products. In addition, over $90 \%$ of the articles were found to be published in developed countries. Figure 1 shows the flowchart (review framework) that guided the literature selection process, while Table 1 provides a summary of the papers. 


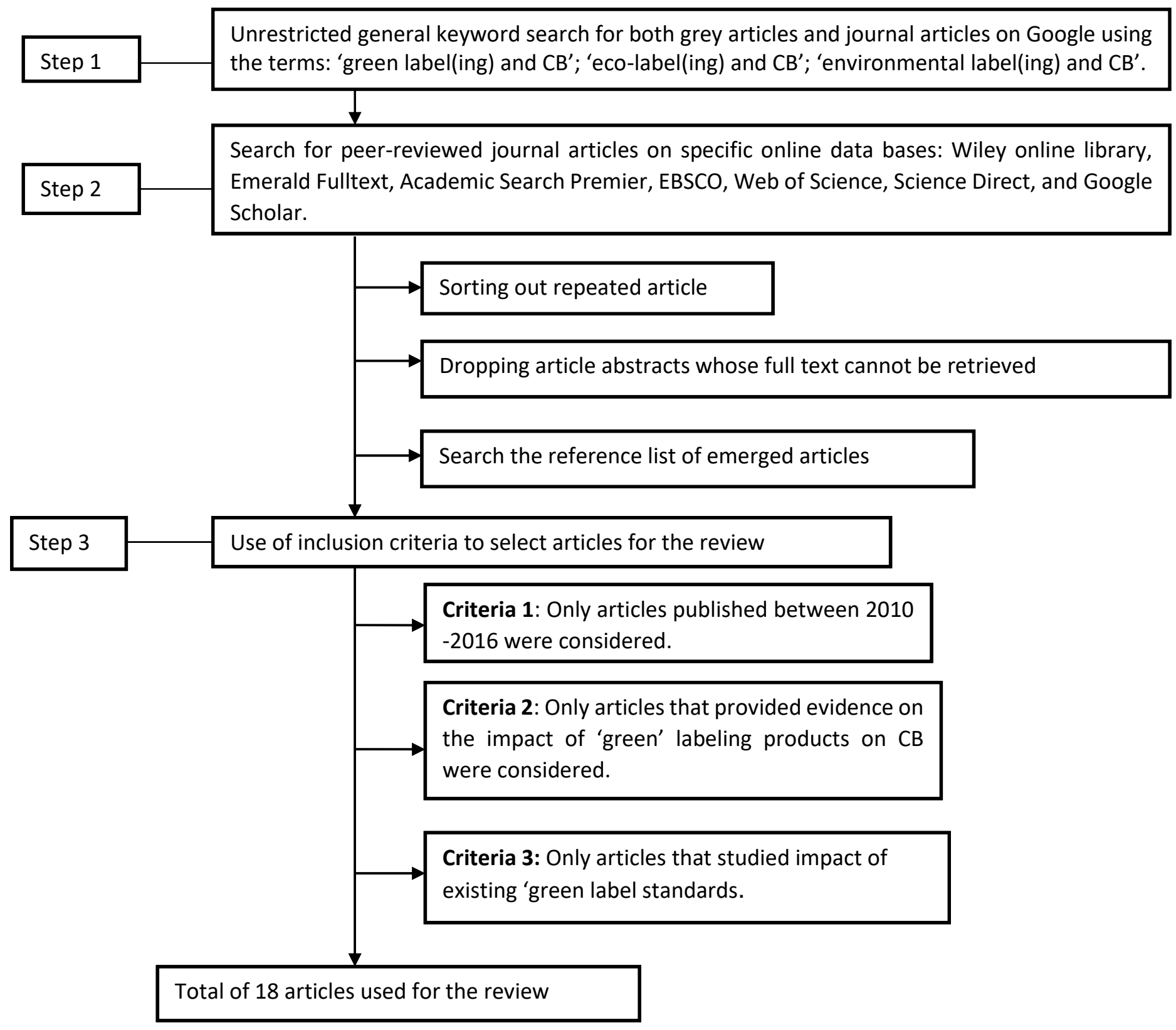

Figure 1: Flow chart of literature selection process

\section{Result Synthesis}

Since the aim of the review is to provide evidence on what impact 'green' product labels have had on $\mathrm{CB}$, the selected articles were synthesised according to their findings and conclusions on the nature of impact 'green' product label standards have had on CB. The following themes were identified:

1. Positive impact

2. Negative impact

3. Mixed impact 
4. Zero impact

Positive impact articles provided evidence that the presence of a 'green' label on a product triggered either a 'green' neutral consumer to consider the environmental impact of his/her consumption and possibly begin to purchase green certified products, or facilitated the 'green' purchasing of a pro-environmental consumer. Negative impact articles provided evidence that the proliferation of green label products in the market today has, instead of driving or aiding green purchasing, confused consumers who have doubts about the integrity of the labels. Although the negative impacts of 'green' product label standards on CB have been scarcely studied, few evidences suggest that the profusion of eco-labels in the market today have raised the issue of trust, transparency, and authenticity of eco-labels, which has limited its effective use to facilitate green purchasing by green consumers. Mixed impact articles are articles whose findings and conclusions suggest that the presence of a 'green' label on a product had mix impacts on $\mathrm{CB}$, both good and bad. Finally, the zero impact category provided evidence that the presence of a green label on a product does not influence the consumers' purchasing decision in any way. Table 1 presents the summary of the data used for the review. 


\section{Table 1: Summary of data used for the review}

Articles concluding that 'green' product labels have positive impacts on CB

\begin{tabular}{|c|c|c|c|c|c|c|}
\hline$S / N$ & Title of article & Author(s) & Year & $\begin{array}{l}\text { Country/Reg } \\
\text { ion }\end{array}$ & $\begin{array}{c}\text { Industry } \\
\text { sector/product }\end{array}$ & "Green" Label \\
\hline 1 & $\begin{array}{l}\text { Willingness to Pay for Eco-Certified } \\
\text { Refurbished Products: The Effects of } \\
\text { Environmental Attitudes and Knowledge }\end{array}$ & $\begin{array}{l}\text { Harms and } \\
\text { Linton }\end{array}$ & 2015 & Netherlands & Refurbished products & EU Ecolabel \\
\hline 2 & $\begin{array}{l}\text { Why Eco-labels can be Effective Marketing } \\
\text { Tools: Evidence from a Study on Italian } \\
\text { Consumers }\end{array}$ & Testa et al. & 2015 & Italy & $\begin{array}{l}\text { Forest/wood } \\
\text { products, and } \\
\text { general products }\end{array}$ & $\begin{array}{l}\text { FSC Label and EU } \\
\text { Ecolabel }\end{array}$ \\
\hline 3 & $\begin{array}{l}\text { Can Consumers Understand Sustainability } \\
\text { through Seafood } \\
\text { Eco-Labels? A U.S. and UK Case Study }\end{array}$ & $\begin{array}{l}\text { Gutierrez and } \\
\text { Thornton. }\end{array}$ & 2014 & USA and UK & Sea foods & $\begin{array}{l}\text { Dolphin safe label, } \\
\text { MSC, Organic label }\end{array}$ \\
\hline 4 & $\begin{array}{l}\text { Effect of green marketing on consumer } \\
\text { purchase behavior }\end{array}$ & Delafrooz et al. & 2014 & Iran & Food products & Fair trade \\
\hline 5 & $\begin{array}{l}\text { Consumer Decision Making Regarding a } \\
\text { "Green" Everyday Product }\end{array}$ & Thøgersen et al. & 2012 & Denmark & Dairy products & Nordic Swan \\
\hline 6 & $\begin{array}{l}\text { Customer response to carbon labelling of } \\
\text { groceries }\end{array}$ & Vanclay et al. & 2010 & Australia & Groceries & Carbon Trust Label \\
\hline
\end{tabular}


7 Consumer responses to ecolabels

8 Eco-labels and willingness to-pay: a Hong Kong study
Thøgersen et al. 2010 Denmark

Yau
2012 Hong-Kong

Building
Dolphin safe and MSC labels

BEAM Label

\section{Articles concluding that 'green' product labels have mixed impacts on CB}

9 Consumer preference attributes in plants:

evidence from experimental auctions
Yue and

Campbel

2015

USA

Food \&

Agriculture

Green seals

Green Seal and EPA label

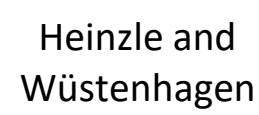

2012

Germany

Consumer electronics

EU Energy label Schemes and Consumer Choice - the Revision of the EU Energy Label as a Missed Opportunity?

12 Consumers' perceptions of individual and

Sirieix

2012 UK Food industry combined sustainable food labels: a UK pilot investigation

Organic Lable, Fair trade(FT), Carbon footprint label, 
13 EU Ecolabel for food and feed products - Sengstschmid feasibility study

14 Investigation of green marketing tools' effect on consumers' purchase behavior

\section{Rahbar and Wahid}

et al.

Organic

growers.

2011

EU

Food industry

EU eco-label

farmers

eco-label

2011 Malaysia General product

SIRIM Eco-Label

Articles concluding that 'green' product labels have zero impact on CB

15 Are French consumers ready to pay a premium for eco-labeled seafood products? A contingent valuation estimation with heterogeneous anchoring.
Salladarr'e
2016
French
Sea foods

MSC label

16 Consumers' preferences for eco-friendly appliances in an emerging market context.

17 Impact of Eco-Friendly Products on Consumer Behavior

18 An Overview of Ecolabels and Sustainability Certifications in the Global Marketplace

\begin{tabular}{|c|c|c|c|c|}
\hline $\begin{array}{c}\text { Sonnenberg et } \\
\text { al. }\end{array}$ & 2014 & South Africa & Washing machine & Energy Star \\
\hline Sehgal et al. & 2010 & $\begin{array}{l}\text { General } \\
\text { review }\end{array}$ & $\begin{array}{l}\text { Textile and Apparel } \\
\text { industry }\end{array}$ & $\begin{array}{l}\text { Global organic textile } \\
\text { standard. }\end{array}$ \\
\hline Golden & 2010 & $\begin{array}{c}\text { General } \\
\text { industry } \\
\text { report }\end{array}$ & $\begin{array}{l}\text { Food and Agriculture, } \\
\text { Textile and Apparel, } \\
\text { Consumer } \\
\text { electronics, } \\
\text { personal and } \\
\text { products }\end{array}$ & $\begin{array}{lr}\text { FT, MSC, } & \text { Global } \\
\text { Organic } & \text { textile } \\
\text { standard, } & \text { Organic } \\
\text { label, } & \text { Rainforest } \\
\text { Alliance Certified }\end{array}$ \\
\hline
\end{tabular}




\section{Analytical Framework}

This review adopted a framework developed by Gupta et al. (2006) for modeling the impact of business programs on customer lifetime value (CLV). Customer lifetime value refers to the net profit a company obtains from its relationship with consumers over a long period of time (Gupta et al., 2006). In the framework, they recognised 3 impacts that business marketing programmes can have on consumers' values (Figure 2). These impacts are manifested in three ways; customer acquisition, customer retention, and customer purchasing.

In the framework,

1. Customer acquisition depicts the scenario where a business marketing strategy or programme attracts new customers, as well as enhances consumers' intention to buy.

2. Customer retention represents a business marketing programme that retains the loyalty of old customers.

3. Customer purchasing refers to business marketing programmes that influences consumers to purchase more of a particular product or brand.

According to Gupta et al. (2006), companies have been using this model to create and sustain longterm relationship with their customers, influence $C B$, assess the impact of their marketing strategies on consumers, as well as manage and measure the success of their business programmes. The framework shows that a firm's business action influences $C B$, which in turn affects the profit making goal of the firm.

The framework was chosen as it uniquely specifies three distinct areas of $C B$ in which every business marketing programme/strategy impacts. Since 'green' label standards are used as marketing tools by businesses to differentiate their product, and attract green consumers, the framework serves as a good starting point to assess the impact of 'green' label standards on different areas of CBs. Furthermore, these three areas of CB identified by Gupta et al. (2006) can be linked to the 3 objectives for the development and use of eco-labels in business.

1. To differentiate a product as eco-friendly, and initiate the concept of green in consumers' consumption decision. Here, the aim of product differentiation is to attract customers (Customer acquisition).

2. Facilitate green purchasing, hence retaining the patronage of pro-environmental consumers (retention behaviour).

3. Influence consumers to purchase more eco-friendly products (purchasing behaviour). The graphical representation of Gupta et al.'s framework is presented in Figure 2. 


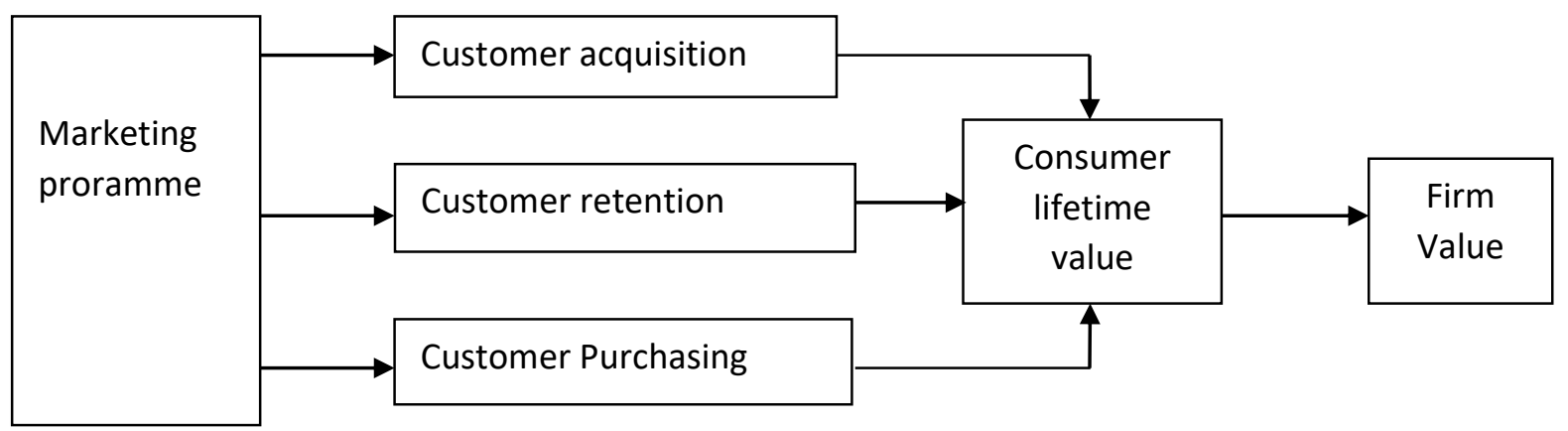

Figure 2: Modeling the impact of business programme on consumer lifetime value (Gupta et al., 2006 p.140)

However, in order to adapt the framework to suit the subject of study in this report, as well as incorporate other impacts of 'green' product label standards on CB identified during the review process that were not in the baseline framework, there was need to adjust the initial framework. This led to the development of a new framework (Figure 3). The new framework had two additional components (consumer confusion and zero impact). While the components in the baseline framework suggest positive impacts of 'green' product labels on consumer behavior, the two additional components in the modified framework shows the negative and neutral impact of 'green' product labels on CB.

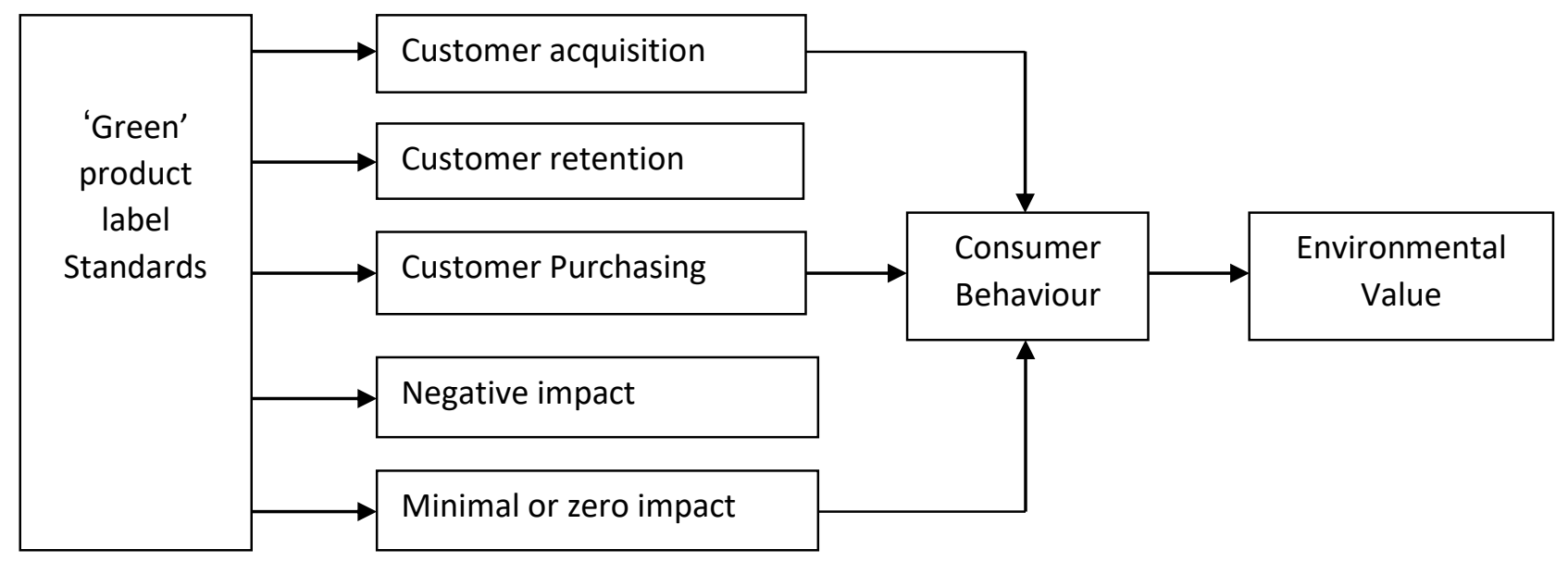

Figure 3: Impact of 'green' product label Standards on CB

\section{Results}

After a critical review and evaluation of the 18 articles, their results and conclusions are presented below in line with the modified framework. 


\section{Customer Acquisition}

Gupta et al. (2006) in their model of CLV explores business approaches that influence new consumers' intention to buy. In the review of articles for this report, Testa et al. (2015), Harms and Linton (2015), Gutierrez and Thornton (2014), and Vanclay et al. (2010) all provided evidences which showed that the presence of 'green' label standards on products have not only attracted new customers to consider the environmental impacts of their purchasing, but have also enabled consumers to understand and begin to appreciate and incorporate the concept of sustainability in their consumption decisions. Using the Dolphin safe label and Organic label as test studies, Gutierrez and Thornton (2014) found that the presence of these labels on sea foods prompted new consumers to consider buying sustainable sea foods, thereby initiating 'green' purchasing from eco-neutral consumers.

Similarly, Vanclay et al. (2010) in their experimental research on consumers' response to carbon labeling of groceries found that immediately 'green' labels where introduced into the sample, there was a fast switch from high carbon to low carbon emission goods by consumers. It was also found that the presence of a green label on groceries drew the attention of buyers to the environmental consequences of their choice of products, stimulating their convictions to become pro-environmental consumers. Although they found that price of products seems to interfere with consumers' decision to buy 'green' products, the presence of eco-label provided sufficient motivation to go for the green product. However, Vanclay et al.'s methodology of involving the media to create awareness about the 'green' labels before the data were collected may have biased the consumers to make positive response towards the 'green' labeled products, thereby limiting the reliability of the result.

Nevertheless, In a similar study in the forest and wood product industry, Testa et al. (2015) found that wood products that have the Forest Stewardship Council (FSC) label commanded more patronage from consumers more than wood products without the label. The overall effects of this increase in demand for eco certified products will according to Testa et al. (2015) incentivise producers to produce more sustainable products, as well as for retailers to sell more sustainable goods, which will at the end promote environmental wellbeing. Apart from increasing demand for sustainably produced products, eco-label as a marketing tool influenced consumer choices to consider 'green' attributes in their purchasing decisions (Thøgersen et al., 2012).

\section{Customer Retention}

Gupta et al. (2006) made it clear that sometimes, when consumers decide to purchase a commodity, they consider not only the price, but also how the product reflect their perception, social image, values and norms. Hence most CBs are driven by self-conviction. However, there are external factors that influence such personal convictions which can be used by businesses to retain the loyalty of their customers. One way to influence consumers and retain their patronage is to provide product features which appeals to their values (Gupta et al., 2006). In the same vein, Heinzle and Wüstenhagen (2012) found that the use of eco-labels to overcome information asymmetry satisfies the green consumerism value of pro-environmental consumers, which has retained their loyalty to green consumption. Thøgersen et al. (2010) in their study about consumers' response to eco-labels in Denmark reported that the MSC label aided eco-friendly consumers to separate sustainable sea foods from conventional sea foods which facilitated their shopping, and consequently retained their 
patronage of eco-friendly sea foods. Apart from Heinzle and Wüstenhagen's article, and Thøgersen et al.'s article, there was no other literature that met the inclusion criteria for this review, that provided evidence or sugestion that the use of eco-labels have influence the retention behaviour of consumers towards green products.

\section{Customer Purchasing}

The third component of the baseline framework is customer purchasing- which aims at influencing the purchasing behaviour of consumers (Gupta et al., 2006). In line with Gupta et al.'s finding that differentiating a product with a unique feature is one way of influencing consumers' purchasing behaviour, Testa et al. (2015), Delafrooz et al. (2014), and Gutierrez and Thornton (2014) found that eco-label, as a unique product feature has influenced consumers' purchasing behaviour. Testa et al. (2015) however reported that eco-labels do not have equal impact on consumers. For instance, proenvironmental consumers do not necessarily consider price when it comes to purchasing 'green' labeled products. But for price sensitive consumers, once the price of a green product is significantly higher than the conventional product, the former is sacrificed for the latter. Although 'green' consumers do not consider price when it comes to purchasing green products, the findings from Whitson et al. (2014) suggests that no rational consumer will sacrifice quality of product for environmental concerns.

In their studies, Harms and Linton (2015), Yue and Campbell (2015), Gutierrez and Thornton (2014), and Rahbar and Wahid (2011) all found that 'green' labels encouraged willingness to pay for green products on the part of the consumers. For instance, Gutierrez and Thornton (2014) reported that consumers when presented with two products of equal value, but one product has a Marine Stewardship Council (MSC) label on it, while the other product has not, consumers were more willing to pay extra for the MSC labeled product. This suggests that the presence of eco-label on a product altered the conventional CB from price-driven purchasing to eco-friendly purchasing.

Harms and Linton (2015) concluded that the willingness to pay for eco certified refurbished products differ across different products. For example, consumers were willing to pay for eco-certified refurbished cameras more than eco certified refurbished tires. This variation across these two refurbished products could be because the consequences of failure in the use of eco certified refurbished tires will be more tragic than failure in using eco certified refurbished cameras. Hence, irrespective of the environmental attribute, consumers are not willing to risk safety of life for environmental concerns.

\section{Negative Impact}

Green labels are meant to promote the purchasing of green products. But surprisingly, Sengstschmid et al. (2011) in their industry report on the impact of EU eco-labels for food and feed industry in Europe found that too many eco-labels in the food industry have actually confused consumers about which label to trust. According to the report, the issue of popularity and familiarity with a label generates the question of trust on the authenticity of a label especially now that the issue of 'green washing' is becoming more prevalent in the market. To enhance consumer adoption of eco-labels 
and influence on $\mathrm{CB}$, they recommended an industry-wide label instead of individual companies or retailers to have their own proprietary labels as competitive differentiator.

However, although the findings by Sirieix et al. (2012) shows that familiar and popular eco-labels influence CBs more than unpopular ones, there's probability that the industry report by Sengstschmid et al. may be biased to favour the EU eco-labels to dominate the EU food industry. Since most independent studies have found positive impacts of eco-labels, it may not be wise to rely on an industry report to conclude that eco-labels have negative impact on $\mathrm{CB}$.

On the other hand, Gutierrez and Thornton (2014) found that too much generic sustainability information on a label tends to confuse consumers. For instance, seafood eco-labels like Friends of the sea and MSC label, both of which deal with lots of marine sustainability issues had unintended and negative effect on CB in USA and UK when compared with eco-labels like Dolphin Safe and Organic labels which had more specific information (Gutierrez and Thornton (2014). They thus concluded that the generalisation of sustainability information on most eco-labels confuse consumers. However, this finding may not be sufficient to conclude that eco-labels have negative impacts on CB. Since it is the manner in which the sustainability information are presented that is causing consumer confusion and not the eco-label itself, the problem may be corrected by disclosing specific product information about the 'greenness' of a product. Companies such as HP have used this approach to promote the 'greenness' of their products with their launch of 'eco-highlights label on their products (Heinzle and Wüstenhagen, 2012).

Additionally, Yau (2012) in his study about the willingness of consumers to pay for eco-certified buildings in Hong Kong found that the numbers of respondents who are willing to pay for the buildings dropped significantly on learning that the buildings are eco-certified. This however might not be unconnected to the relative higher prices associated with eco-certified buildings. Coupled with the fact that Hong Kong is still a developing country where prices play a major role in influencing $C B$, the probability that the Hong Kong consumers will be more loyal to their economic needs than environmental concerns is high. This is a bit different from consumers' behaviours in developed countries where environmental concerns are strong in influencing consumers.

\section{Minimal or Zero Impact}

There still exist studies suggesting that eco-labels have little or no impact in influencing CBs. Sehgal et al. (2010) found that although eco-labels have created awareness of sustainable apparels in the textile industry, they have not succeeded in influencing consumers to eco-friendly purchasing. In the same vein, the report of the industry review by (Golden, 2010) found very little empirical evidence that linked eco-labels with improved CB towards the environment. Although the findings of this report may have been limited by its narrow scope and sample size, a more recent finding by Salladarr'e (2016) found that willingness to pay for eco-certified sea foods in France was determined by socio-economic factors such as income, price of commodity, quality of products, etc, and not by eco-labels. The introduction of MSC label into the study was found to have no effect in influencing consumers to purchase green products. Although the author acknowledged that non observance of other systematic changes in the market may affect the reliability of their result, the report nevertheless also agrees with the findings of Sonnenberg et al. (2014) who found that the Energy Star Label had no effect in influencing consumers to purchase eco-certified washing machine in South 
Africa, as consumers prioritised price and brand over green labels. These findings suggest that ecolabels alone may not be sufficient to influence CB. There may be need for more awareness creation and public enlightenment on the importance of eco-labels in identifying sustainable products.

\section{Conclusion}

This review has explored the various impacts that 'green' product label standards have had on CB. The major findings of the study shows that although consumers are becoming more environmentally responsible, and eco-labels have played a role in facilitating green purchasing, the overall impact of eco-labels on $C B$ is varied. Evidence abounds of both positive and negative impacts, with little evidence of no impact in some cases. However, it is apparently clear from this review that 'green' product label standards have:

1. influenced eco-neutral consumers to begin to consider and incorporate the concept of sustainability in their purchasing decisions; and

2. been able to facilitate the green shopping attitude of pro-environmental consumers, retaining their purchase of green products.

A summary of how eco-labels positively impacted $C B$ to enhance environmental wellbeing is presented in Figure 4 below.

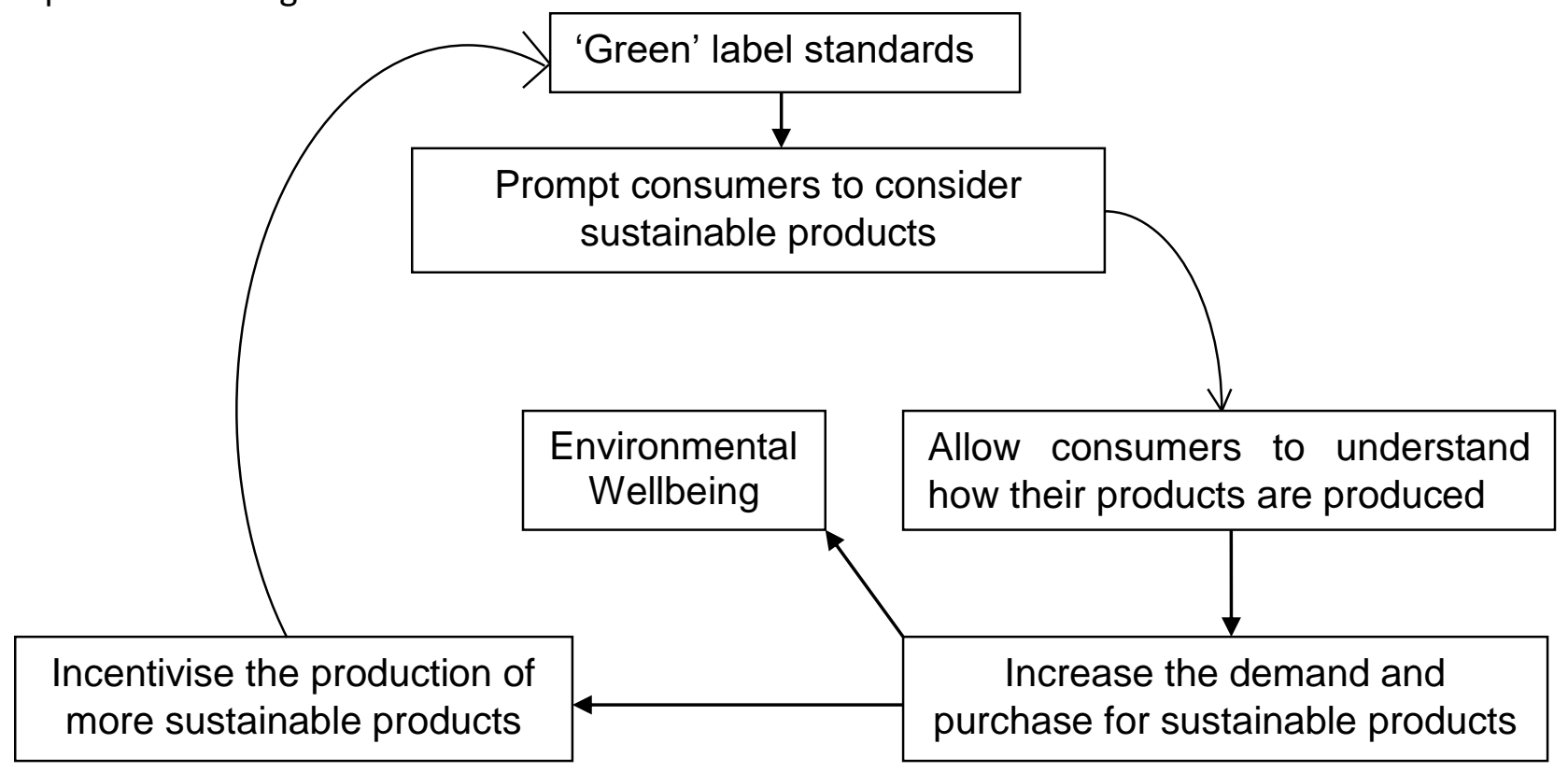

Figure 4: Positive impact of 'green' products label standards on CB

Although 'green' product label standards were reported to have some negative impacts on $C B$, especially with regard to consumer confusion following the profusion of 'green' labels in the market, more independent studies are needed to verify this finding.

Finally, it was noticed that available researches on the impact of 'green' product label standards on $\mathrm{CB}$ have concentrated on the consumer purchasing behaviour. No recent study was found on the impact of 'green' labels on product utilization and disposal, which also forms part of CB. Purchasing green labeled product (green consumerism) may not automatically translate to sustainable 
consumption. Consumers may purchase green products, but if they do not consume and dispose appropriately, it may not produce the intended effect of reducing the environmental impact of consumption. Since the goal of using eco-labels to influence CB is to allay the environmental impact of consumption on the environment, the contribution of 'green' product label standards to sustainable consumption can thus not be concluded only from the available evidence on purchasing behaviour. It is therefore critical to widen the scope of research to also ascertain what impacts green' product label standards have had on product utilisation and disposal. Nevertheless, it is clear from the available evidence that 'green' product label standards have positively impacted consumers' purchasing behaviour.

\section{Références}

Brécard, D., Hlaimi, B., Lucas, S., Perraudeau, Y., \& Salladarré, F. (2009). Determinants of demand for green products: An application to eco-label demand for fish in Europe. Ecological Economics ,69(1),115-125. Available from: http://dx.doi.org/10.1016/j.ecolecon.2009.07.017.

Connell, K.Y. (2010). Internal and external barriers to eco-conscious apparel acquisition International Journal of Consumer Studies, 34(6), 279-286.

Dagher, G.K. \& Itani, O. (2014). Factors influencing green purchasing behaviour: Empirical evidence from the Lebanese consumers. Journal of Consumer Behaviour, 13(195), 188-195.

Delafrooz, N., Taleghani, M. \& Nouri, B. (2014). Effect of green marketing on consumer purchase behavior. Q Science Connect, 5(10),1-9. Available from: http://dx.doi.org/10.5339/connect.2014.5

Gallastegui, I.G. (2002). The use of eco-labels : a review of literature. European Environment, 12 (331), 316-331.

Ghafelehbashi, S. (2011). Acquaintance with all types of involvement in consumer behaviour. Interdisciplinary Journal of Contemporary Research in Business, 3(5), 493-507.

Golden, J. (2010). An Overview of Ecolabels and Sustainability Certifications in the Global Marketplace. Interium report. Corporate sustainability initiative: Nicholas Institute for Environmental Policy Solutions, Duke University.

Gutierrez, A. \& Thornton, T.F.( 2014). Can consumers understand sustainability through seafood EcoLabels: A U.S. and UK Case Study. Sustainability 6(11), 8195-8217. Available from: http://www.mdpi.com/2071-1050/6/11/8195

Gupta, S., Hanssens, D., Hardie, B., Kahn, W., Lin, N., Ravishanker, N., and Sriram. 2006. Modeling Customer Lifetime Value. Journal of Service Research, 9(2), 139-155.

Harms, R. \& Linton, J.D. (2015). Willingness to pay for eco-certified refurbished products: the effects of environmental attitudes and knowledge. Journal of Industrial Ecology, 44(10),1-12. Available from: http://onlinelibrary.wiley.com/doi/10.1111/jiec.12301

Heinzle, S.L. \& Wüstenhagen, R.( 2012). Dynamic adjustment of Eco-labeling schemes and consumer choice - the revision of the EU Energy Label as a missed opportunity? Business Strategy and Environment, 21(1), 60-70. Available from: http://onlinelibrary.wiley.com/doi/10.1002/bse.722.

Horne, R.E. (2009). Limits to labels : The role of eco-labels in the assessment of product sustainability and routes to sustainable consumption. International Journal of Consumer Studies, 33(9), 175-182.

Kast, S.W. (2003).Promoting sustainable consumption: Determinants of green purchases by Swiss consumers.Psychology and Marketing, 20(10), 883-902. 
INTERNATIONAL JOURNAL OF ACADEMIC RESEARCH IN BUSINESS AND SOCIAL SCIENCES Vol. 8, No. 9, Sept. 2018, E-ISSN: 2222-6990 @ 2018 HRMARS

Konuk, F.A., Rahman, S.U., Salo, J. (2015). Antecedents of green behavioral intentions : a crosscountry study of Turkey , Finland and Pakistan. International Journal of Consumer Studies. 39 (6), 586596.

Manzano, N., Rivas, L., \& Bonilla, G. (2012). Explanatory models of change of consumer behaviour applied to social marketing. Scientific Research, 4(3), 246-255. Available from: http://www.SciRP.org/journal/ib.

Moher, D. Shamseer, L., Clarke, M., Ghersi, D., Liberati, A., Petticrew, M., Shekelle, P., \& Stewart, L. (2015). Preferred reporting items for systematic review and meta-analysis protocols (PRISMA-P) statement. Syst. Rev. 4(1), 1-9. doi: 10.1186/2046-4053-4-1

Rahbar, E. \& Wahid, N.A. (2011). Investigation of green marketing tools ' effect on consumers' purchase behaviour. Business Strategy Series, 12(2),73-83. Available from: http://www.emeraldinsight.com/doi/abs/10.1108/17515631111114877.

Rourke, D.O. \& Ringer, A. (2015). The Impact of sustainability information on consumer decision making. Journal of Industrial Ecology. 44(223), 1-11.

Royne, M.B., Levy, M. \& Martinez, J. (2011). The public health Implications of Consumers ' environmental concern and their willingness to pay for an eco-friendly product. Journal of Consumer Affairs, 45(2), 329-343.

Salladarré, F., Brécard, D., Lucas, S., \& Ollivier, P. (2016). Are French consumers ready to pay a premium for eco-labeled seafood products ? A contingent valuation estimation with heterogeneous anchoring. Agricultural Economics, 47(2),247-258. Available from: http://onlinelibrary.wiley.com/doi/10.1111/agec.12226

Sammer, K. \& Wüstenhagen, R. (2006). The Influence of eco-labelling on consumer behaviour results of a discrete choice analysis for washing machines. Business and Strategy, 15(3), 185-199. Santos, M.A.O. (2007). Minimizing the business impact on the natural environment: a case study of Woolworths South Africa.European Business Review. 23(4), 384 - 391.

Scott, L. \& Vigar-ellis, D. (2014). Consumer understanding, perceptions and behaviours with regard to environmentally friendly packaging in a developing nation. International Journal of Consumer Studies,38(6), 642-649. Available from: http://onlinelibrary.wiley.com/doi/10.1111/ijcs.12136

Sehgal, M.P. (2010). Impact of eco-friendly products on consumer behaviour. CBS E-Journal, 6(1), 116. Available from: http://www.cbsmohali.org/img.

Sengstschmid, K., Sprong, N., Schmid, O., Stockebrand, N., Stolz, H., \& Spiller, A. (2011). EU Ecolabel for food and feed products - feasibility study. A report for DG Environment, European Commission Sirieix, L., Delanchy, M., Remaud, H., Zepeda, L. \& Gurviez, P. (2012). Consumers ' perceptions of individual and combined sustainable food labels : a UK pilot investigation. International Journal of Consumer Studies, 37(2),143-151. Available from: http://onlinelibrary.wiley.com/doi/10.1111/j.1470-6431.2012.01109

Sonnenberg, N.C., Erasmus, A.C. \& Schreuder, A. (2014). Consumers ' preferences for eco-friendly appliances in an emerging market context. International Journal of Consumer Studies, 38(5), 559569. Available from: onlinelibrary.wiley.com/doi/10.1111/ijcs.12120.

Testa, F., Iraldo, F., Vaccari, A., \& Ferrai, E. (2015). Why Eco-labels can be Effective Marketing Tools: Evidence from a Study on Italian Consumers. Business Strategy and Environment,24(4),.252-265. Available from: http://onlinelibrary.wiley.com/doi/10.1002/bse.1821 
INTERNATIONAL JOURNAL OF ACADEMIC RESEARCH IN BUSINESS AND SOCIAL SCIENCES

Vol. 8, No. 9, Sept. 2018, E-ISSN: 2222-6990 @ 2018 HRMARS

Thøgersen, J., Haugaard, P., \& Olesen, A. (2010). Consumer responses to ecolabels. European Journal of Marketing, 44(11), 1787-1810. Available from: http://www.emeraldinsight.com/doi/abs/10.1108/03090561011079882.

Thøgersen, J., Jørgensen, A., \& Sandager, S. (2012). Consumer decision making regarding a "green" everyday product. Psychology and Marketing, 29(4),187-197. Available from: http://onlinelibrary.wiley.com/doi/10.1002/mar.20514

Vanclay, J., Shortiss, J., Aulsebrook, S., Gillespie, A., Howell, B. \& Johanni, B. ( 2011). Customer response to carbon labelling of groceries. Journal of Consumer Policy ,34(1),153-160. Available from: www.springerlink.com, http://dx.doi.org/10.1007/s10603-010-9140-7.

Vanyushyn, V. (2011). Communicating to consumers in Sweden with eco-labels: is the message gettinh through? Umea School of Business.

Whitson, D., Ozkaya, E. \& Roxas, J. (2014). Changes in consumer segments and preferences to green labelling. International Journal of Consumer Studies, 38(5), 458-466. Available from: http://onlinelibrary.wiley.com/doi/10.1111/ijcs.12103.

Yau, Y. (2012). Eco-labels and willingness- to-pay : a Hong Kong study. Smart and Sustainable Built Environment 1(3),277-290. Available from: http://www.emeraldinsight.com/doi/abs/10.1108/20466091211287146

Yue, C. \& Campbell, B. (2015). Consumer Preference for Sustainable Attributes in Plants : Agribusiness International Journal, 32(2),pp.1-14. Available from: http://onlinelibrary.wiley.com/doi/10.1002/agr.21435.

Zepeda, L., Sirieix, L., Pizarro, A., Corderre, F. \& Rodier, F. (2013). A conceptual framework for analyzing consumers' food label preferences: An exploratory study of sustainability labels in France , Quebec , Spain and the US. International Journal of consumer studies, 37(6),605-616. Available from: http://onlinelibrary.wiley.com/doi/10.1111/ijcs.12041. 